\title{
A Beautiful Stroke? A Side Note on the 75th Anniversary of the Spectacular Death of the French Organist and Composer Louis Vierne (1870-1937)
}

\author{
Christian Foerch $^{a}$ Sophie Lemercier ${ }^{a, c}$ Michael G. Hennerici ${ }^{b}$ \\ a Department of Neurology, Goethe University, Frankfurt am Main, and b Department of Neurology,

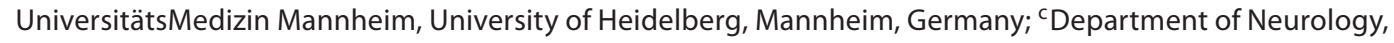 \\ Hospital of Pontchaillou, Rennes, France
}

\section{Key Words}

Vierne $\cdot$ Organist $\cdot$ Death $\cdot$ Stroke $\cdot$ Heart attack

\begin{abstract}
The great French organist and composer Louis Vierne (18701937) died while performing an organ recital at Notre Dame cathedral in Paris - right in front of the console. This historical article provides insights into the biography of a highly talented musician who was challenged by disability and diseases throughout his career. A special focus is placed on the circumstances of Vierne's remarkable death. Until now, both a primary cerebrovascular event and a 'heart attack' are discussed in reference books and encyclopedias as the immanent causes of death. From the perspective of a stroke neurologist, a reappraisal of Vierne's medical history and the events that happened during his last concert is presented.
\end{abstract}

Copyright $\odot 2012$ S. Karger AG, Basel

A big event was announced for the evening of June 2, 1937 at Notre Dame de Paris. That Wednesday, the French organ association, Les Amis de l'Orgue, was going to celebrate its 10th anniversary with a master concert. More than 3,000 people filled the cathedral, awaiting a pure organ recital an hour or two long, with Louis Vierne and Maurice Duruflé playing an 'all Vierne' program. Vierne was the famous organiste titulaire (fig. 1) and Duruflé, one of his most talented students, was organiste suppléant, who later became organiste titulaire at St. Étiennedu-Mont de Paris [1].

The concert started with Vierne playing the Triptyque pour Grand Orgue, a three-setter (of course) of about 15 min duration which he composed only a few years before. The first 'table' of the triptych called Matines is a quiescently flowing movement that imitates the ringing of church bells, depicting the religious atmosphere of an early Sunday morning [1].

Louis Vierne was born on October 8, 1870 in the French town of Poitiers. From birth on he suffered from 'blindness' caused by a congenital cataract. Vierne described later on that he could see enough to be able to walk without assistance, to recognize persons, to identify objects nearby and to read large letters directly in front of his eyes [2]. However, his visual problems made it necessary for him to undergo a special education for handicapped children. His uncle, Charles Colin, a well-known French organist and oboist, detected Vierne's extraordi-

\section{KARGER}

Fax +4161306 1234

E-Mail karger@karger.ch

www.karger.com
C) 2012 S. Karger AG, Basel

$1015-9770 / 12 / 0344-0322 \$ 38.00 / 0$

Accessible online at:

www.karger.com/ced
Christian Foerch, MD

Department of Neurology, Goethe University

Schleusenweg 2-16

DE-60528 Frankfurt am Main (Germany)

E-Mail foerch@em.uni-frankfurt.de 


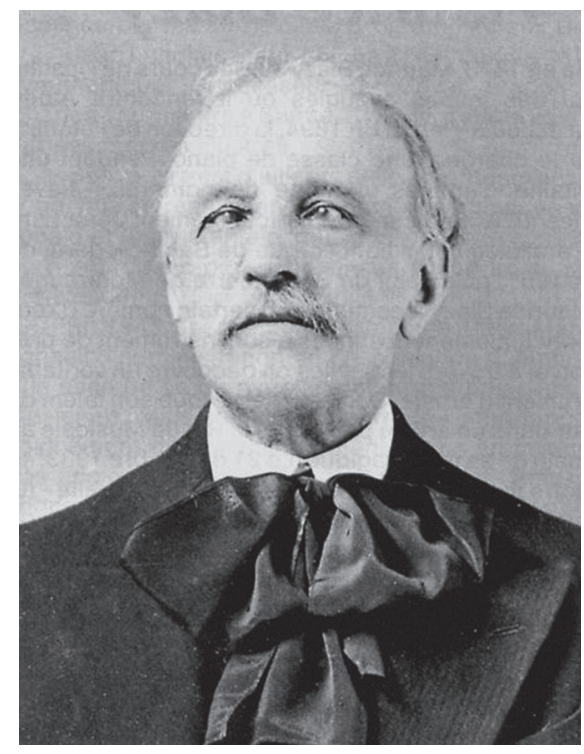

Fig. 1. Louis Vierne (1870-1937) [reprinted with permission, Collection Denis Havard de la Montagne; www.musimem.com].

nary talent for music early on. In his autobiography Mes Souvenirs, Vierne describes it as one of the mystic moments in his life, when he heard a church organ playing for the first time. From this time point on, his only aim was to become an organist [2]. At the age of 11 years he was admitted to the Institution Nationale des Jeunes Aveugles in Paris, a special school for blind students. He was trained on the organ and the piano and also had violin lessons. After his graduation, no one less than César Franck, the most recognized organist in the second half of the 19th century, who is nowadays considered to be the spiritus rector of the French symphonic organ style, invited Vierne to join his master class at the Paris Conservatoire in 1889 [2].

After the final chord of the first movement had faded away in the cathedral, Vierne started with the second 'table' of the Triptyque. The Communion is an emotive and gentle piece of music based on a simple theme, but with a complex harmonic structure. It leaves room for meditation and rest [1].

After the surprising early death of Franck in 1890, the master class at the Conservatoire was taken over by Charles Marie Widor, another star of the French organ music genre, whose Toccata in $F$ is nowadays among the most popular organ pieces in the world. Not long thereafter, Vierne got a job as Widor's assistant organist at the church of Saint-Sulpice (the second largest in Paris), where in 1934 the famous organist and father of improvisation, Marcel Dupré (1886-1971), was entitled at the big Cavaillé Colle organ. In 1900, the prestigious position of the organiste titulaire at the Cathedral of Notre Dame was vacant. Vierne applied and was selected out of several candidates after a competition (a rare video of Vierne playing at the Grand Orgue at Notre Dame can be viewed [3]). Succeeding Widor's position, Alexandre Guilmant asked him to continue to lead the master class at the Conservatoire until 1911. Vierne was invited to perform in many European countries and also in the United States. While having increasing success as an organist, he had to bear with several familiar drawbacks that unhinged his psychic balance, such as the divorce from his wife Arlette Taskin, the death of his brother in World War I and the deaths of both of his sons [2].

Vierne may have thought of this when starting to play the last part of the Triptyque, called Stele pour un Enfant Défunt (i.e. tombstone for a dead child). This piece combines mystic harmonies and sustained tones with a sentimental melody [1].

From the beginning of his life onwards Vierne had to deal with physical disability and diseases that challenged his musical career. In his autobiography, Vierne described his brother and himself as being of 'weak condition' [2]. As children, both of them barely escaped death during a rubeola infection. In 1906 he suffered from a severe bimalleolar ankle fracture of his right leg after he was stumbling across the tracks of a streetcar. Several attempts were necessary to reset the bones, and Vierne was immobilized by a cast for many weeks. It took him 2 months to learn to walk again, and a much longer time to regain enough skills to operate an organ pedal. A year later he was almost carried off by typhoid fever. In his autobiography, Vierne also describes a painful neuritis (likely a neuralgic amyotrophy), which precluded him from using his right arm for a certain period of time [2]. His disabling visual problems, which were more or less stable during adolescence, started to turn worse from 1915 onwards due to glaucoma. Vierne was forced to adjourn his duties at Notre Dame for as long as 4 years and went to Switzerland for specific treatment there. Vierne was a heavy smoker who apparently also smoked at his working space, the tribune of the Cathedral of Notre Dame. He took various medications, including stimulants and sleeping pills, and the ingestion of ether in times of emotional 'crisis' is reported. Later on in his life, it turned out that it was more and more difficult for him to climb the stairs towards the tribune of Notre Dame due to 'heart problems' [1]. Moreover, after suffering from a severe pneumonia in the win- 
Fig. 2. Program of the organ concert at Notre Dame on June 2, 1937. A visitor noted by hand 'reached this point of the pro-

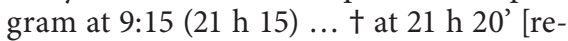
printed with permission from 1].

\section{$\equiv$ PROGRAMME $\equiv$}

I. Triptyque pour Grand Orgue ............. LOUlS VIERNE

1. Matines.

Des carillons, tantot à l'aigu, tantot au grave, enveloppent et à la fois précisent cette impression de religleux matin.

2. Commanion.

Emouvante page, dont un chromatisme discret vient, de temps à autre, rehausser, mals sans Jamais l'interrompre, la lumineuse tendresse.

3. Stile pour un enfant defunt.

Une longue, expressive mélodie, od la mattrise de l'écriture se fait, — particuliérement à la conciusion, I'Interpréte tidéle du sentiment.

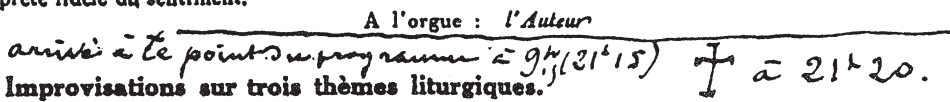

A l'orgue : LOUIS VIERNE

III. Quatre Pibces . . . . . . . . . . . . . . . LOUlS VIERNE

(Extraites des Pideses de Fanlaisis, pour Grand Orgue, en quatro Suitos)

1. Les cloches de Hinckley.

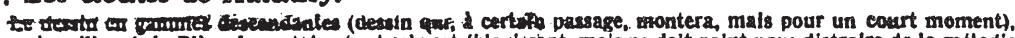

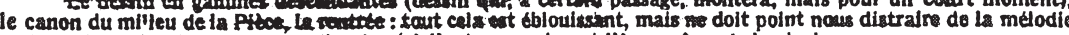
qui, en des voix dlverases, regroo d'mon bout a l'autre, exprimant l'ame méme de la cloche.

2. Clair d

Un chant, d'une charmante et mysterleuse sinuosilté, encadre un très prenant Duo entre soprano et pédale, se développant au sein d'une riche atmosphere sonore, ex par le moyen d'une double pédale, devenant Trio.

3. Sicilienne.

Quel charme mellancollque en cette exquise Sicllenne (mi-mineur), un instant éclairée par la tonalité de mi-majeur, et ornée de précieux dessins, d'abord croches coupées de doubles croches, puis doubles croches uniquement, enfin, pour la rentré, doubles crochess trilolets.

4. Cathedrales.

Que dire de cette admirable erctitecture, sinon qu'un grand musicien a saisi, exprime, avsc quel art souverain, la pensée des « Mattres-maçons " du Moyen age. L'analyse doit, ici, faire place à l'admiration.

IV. Aria et Final do la VI Symphonie. . . . . . . . . . . . LOUlS VIERNE L'Aria est une meditation d'une impressionnante profondeur. Il conclut par le retour, plein de douceur, d'un des eléments constructeurs de la superbe Symphonie. Cette méme Figure Musicale, nous la retrouverons a la pédale, dans l'éclatante combinaison qui couronne le Pinal. Avec ce supreme morceau, de la pre

$$
\text { A l'orgue : MAUAICE DURUFLÉ }
$$

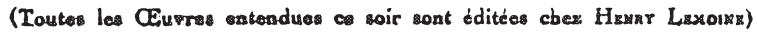

A. DE MONTRICHARD ter of 1935-1936, he was so weakened that other people had to help him to climb the steps to the tribune. Thereafter, he was not able to perform his duties on a regular basis any more. In fact, having a presentiment of death, he already had asked the cleric to find a successor for this job [2].

At the evening of the concert, it is reported that Vierne was picked up at his apartment by his physician and good friend Dr. Lucien Mallet [1]. Norbert Dufourcq is witnessed to have spoken to Vierne after his arrival at Notre Dame and was apparently shocked by the pallor of his face [4]. Vierne finally managed to climb the stairs up to the organ 'slowly and painfully'. Thereafter, he apparently was in such a bad state that Dr. Mallet was constrained to give him two Solucamphre pills [1], containing among others the sympathomimetic agent ephedrine and parasympatholytic substrates derived from Atropa belladonna. The events that followed after Vierne had finished playing the last measures of the Triptyque were witnessed by Duruflé (who sat next to him and pulled the stops) [1, 5]. Vierne turned pale; his right hand trembled and clutched at the manual. 'I can no longer see the keys' he said, and 'I am going to be ill'. Then, he collapsed at the organ with his foot pushing down the low E pedal for a 
while, causing a single tone that echoed through the cathedral. He was dead instantly. The audience was later informed about what happened on the tribune (fig. 2). Prayers were said before Vierne's corpse was moved downstairs to an ambulance car and taken to his apartment.

Duruflé later reported that a stroke ('apoplexie') was the cause of Vierne's death [5], whereas others declared that Vierne had moved one of his hands to his heart just prior to the collapse, suggesting a cardiac problem [6-8]. These and other testimonies of Vierne's remarkable death have found their way into the literature. In reference books and encyclopedias, it has been proclaimed until now that Vierne died either from a stroke or from a heart attack [9]. However, after a critical reevaluation of the patient's medical history and the reports of the witnesses, it seems to be rather unlikely that a stroke was the immediate cause of death. Stroke of whatever subtype is typically not a condition that leads to death within seconds. This accounts also for severe strokes that cause a sudden loss of consciousness (a 'collapse'), such as an occlusion of the basilar artery or a major intracerebral or subarachnoid hemorrhage. In Vierne's case, both headache and the presence of a focal neurological deficit (e.g. hemiparesis or speech disturbances) were never reported. On the other hand, the sudden death, the pallor, Vierne's own reports of a bad cardiological condition and the progressive difficulties to climb the stairs of the tribune (a 'cardiac stress test') make it more likely that a primary cardiac event, particularly a malign arrhythmia, was the immediate cause of death.

Vierne was good in creating extraordinary finales. One is the famous masterpiece that concludes his first organ symphony. The one that concluded his life was exactly what he always wished for himself in his moment of death.

\section{Acknowledgment}

We are very grateful to Hans Steinhaus (Bonn, Germany) for his help in validating the references.

\section{References}

1 Smith R: Louis Vierne - Organist of Notre Dame Cathedral. Hillsdale, Pendragon Press, 1999.

2 Vierne L: Mes souvenirs; in In Memoriam Louis Vierne (1870-1937). Paris, 1939, pp 9-121/Steinhaus H: Louis Vierne - Meine Erinnerungen (German ed). Köln, Dohr, 2004.
$3 \mathrm{http}: / / \mathrm{www} \cdot y o u t u b e \cdot \operatorname{com} / \mathrm{watch}$ ? $\mathrm{v}=$ rJKCaGha7nE (accessed August 5, 2012).

4 Dufourcq N: Quelques souvenirs sur Louis Vierne; in In Memoriam Louis Vierne (1870-1937). Paris, 1939, pp 210-215.

5 Durufle M: Mes Souvenirs sur Tournemire et Vierne. L'Orgue 162, April-June 1977, pp $1-7$.

6 Gavoty B: L'improvisateur; in In Memoriam Louis Vierne (1870-1937). Paris, 1939, pp 156-158.
7 Gavoty B: Louis Vierne, la Vie et l'Oeuvre. Paris, 1943

8 Jaquet-Langlais ML: Ombre et Lumière: Jean Langlais 1907-1991. Paris, Éditions Combre, 1995.

9 http://en.wikipedia.org/wiki/Louis_Vierne (accessed August 5, 2012) 